\title{
Historic and future climatic change in Zimbabwe
}

\author{
Leonard S. Unganai \\ Drought Monitoring Centre, PO Box BE150, Belvedere, Harare, Zimbabwe
}

\begin{abstract}
Near-term and current regional climate patterns for Zimbabwe are summarized based on twentieth-century observation data and model simulations. These records suggest air temperature warming of up to $0.8^{\circ} \mathrm{C}$ and a decline in annual precipitation during the past 60 yr. Future climate scenarios, based on 2 General Circulation Model (GCM) equilibrium models, General Fluid Dynamics Laboratory (GFDL3) and Canadian Climate Centre (CCCM), were developed for Zimbabwe and southern Africa. Both GCMs suggest that with doubling of atmospheric $\mathrm{CO}_{2}$ mean air temperature will increase by 2 to $4^{\circ} \mathrm{C}$. In contrast, these 2 GCMs project different current and future precipitation scenarios for Zimbabwe. When calibrated with observed climate data from Zimbabwe, the CCCM GCM closely simulated current ambient temperature and precipitation patterns. The El Niño Southern Oscillation (ENSO) phenomenon is a major influence on interannual variability of climate in southern Africa. Future African regional climatology projections, based on GCM scenarios, will need to better consider ENSO and other factors if greater precision is to be achieved.
\end{abstract}

KEY WORDS: Climate scenarios · Climate variability $\cdot$ General Circulation Models · Zimbabwe

\section{INTRODUCTION}

Global climate change raises major dilemmas for developing nations such as Zimbabwe. Short-term development goals and the mitigation of existing social, economic and environmental problems may have to be balanced against the need for long-term environmental security and the prospect of chronic climate change (Bolin et al. 1986). The looming possibility of global climate change associated with the greenhouse effect, ozone depletion and land surface changes makes it critical that society anticipate and plan for increased future climate impacts (Houghton et al. 1992).

Climate change is defined as a shift of climatic conditions in a directional incremental mode, with values of climatic elements changing significantly. Evidence of climate change could be detected over several decades (Houghton et al. 1990). While the bulk of past and current greenhouse gas emissions has come from highly industrial nations, it is possible that many of the most serious effects of global climate change will occur in developing countries, mainly because of poverty and the existence of an already heavily degraded environment (Bolin et al. 1986, Houghton et al. 1992). Often, the problem facing developing nations in formulating response strategies to the threat of climatic change is lack of background information on the most probable direction and magnitude of climate change to anticipate. Features of the climate system that are critical for agriculture include: temperature, wind, humidity, atmospheric carbon dioxide $\left(\mathrm{CO}_{2}\right)$, and precipitation. For many agronomic crops, given a sufficient supply of water, increased ambient temperature up to about $40^{\circ} \mathrm{C}$ results in more vegetative growth, while increased $\mathrm{CO}_{2}$ might increase the rate of growth (Idso 1993). Therefore, it is important to quantify these effects if predictions of the impact of climate change on agronomic crop growth are to be assessed (Rosenzweig \& Parry 1994).

The main objective of this study is to obtain requisite climate change information for Zimbabwe, needed to design appropriate future response strategies. Historical instrument records were used to investigate past temperature and rainfall trends in the country and General Circulation Models (GCMs) were used to 
develop the future climate change scenarios for a warmer earth, assuming greenhouse gases to be the main forcing factor (Oppenheimer 1989, Pearman 1991). Although GCMs are used to develop the climate change scenarios, instrument records are used to adjust these scenarios so as to preserve the observed baseline climatic pattern. Precipitation scenarios for the Southern Hemisphere rainy season October to April are presented. For temperature, the annual mean temperature scenarios from different models are presented.

\section{MATERIALS AND METHODS}

Fig. 1 shows the geographical location of Zimbabwe within the southern Africa subregion. Zimbabwe lies between latitudes 15.5 and $22.5^{\circ} \mathrm{S}$ and longitudes 25 and $33^{\circ} \mathrm{E}$. The main topographical feature of the country is the central plateau which is 1000 to $1500 \mathrm{~m}$ above mean sea level. From the central plateau, the altitude decreases northward towards the Zambezi River Valley and southward towards the Limpopo River. The most pronounced mountains in the country are found along the eastern border with Mozambique, where peaks are around 2300 to $2500 \mathrm{~m}$ (Todorov \& Steyaert 1983). Fig. 2 shows the topography and the mean annual precipitation over the country between 1950 and 1980 . The northeast receives about $800 \mathrm{~mm}$ and the south is driest with below $400 \mathrm{~mm}$ annual precipitation. The country's precipitation season spans the

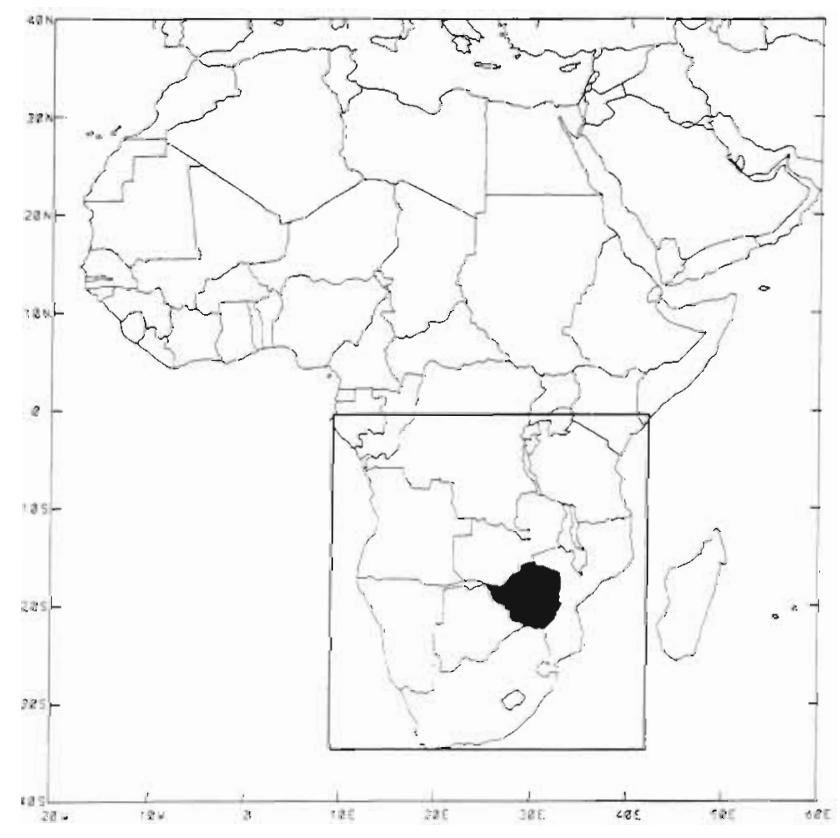

Fig. 1. Geographical location of Zimbabwe

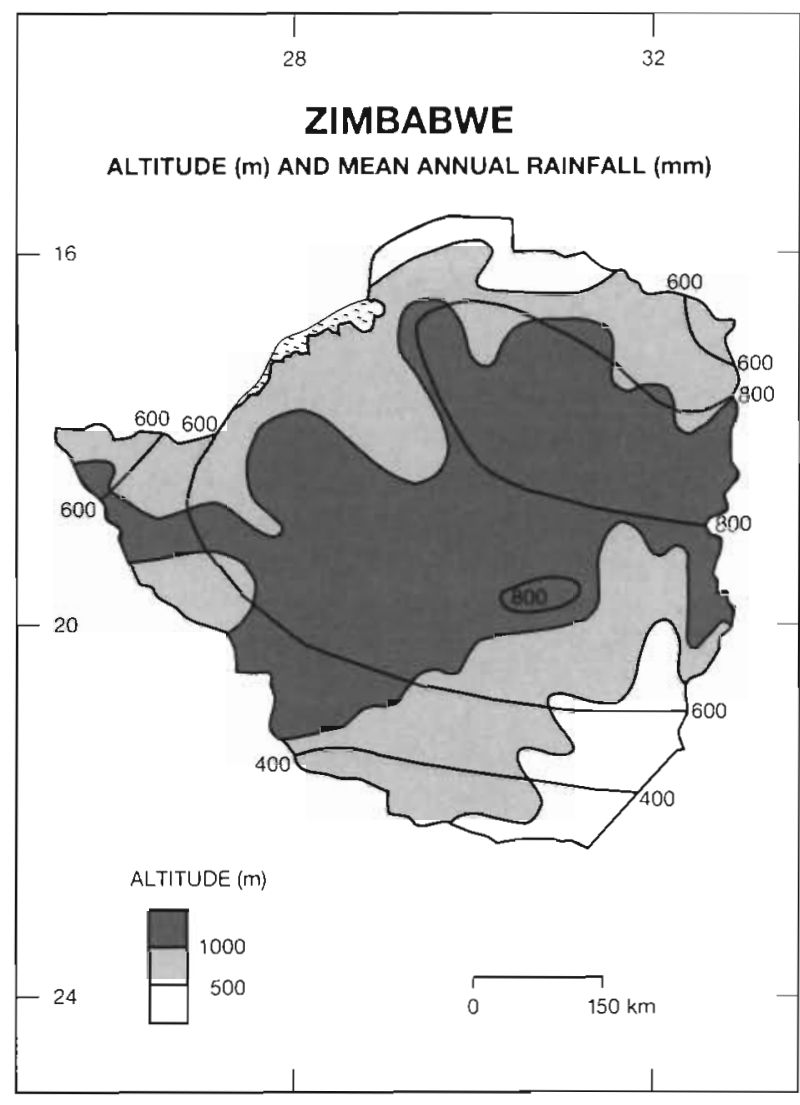

Fig. 2. Altitude and mean annual precipitation for Zimbabwe (Todorov \& Steyaert 1983)

months October through April, with December, January and February being the peak precipitation months. Annual mean temperatures range from $15^{\circ} \mathrm{C}$ on high ground to above $25^{\circ} \mathrm{C}$ in low altitude areas (Climate Handbook of Zimbabwe 1981).

In order to understand, and eventually predict, how increasing atmospheric $\mathrm{CO}_{2}$ concentration might alter the Earth's climate, both modelling studies and empirical analyses of observational data are required. No method exists yet to provide confident predictions of future climate (Pittock \& Salinger 1991, Tucker 1991). Instead, it is customary to specify a number of plausible future climates. These are referred to as climatic scenarios. There are 4 basic types of scenario of future climate namely: historical instrument-based scenarios, paleoclimatic analogue scenarios, arbitrary adjustments, and scenarios from GCM (Pittock \& Salinger 1991). None of these methods is adequate and disagreement will always occur among them. In this paper, climate scenarios based on GCMs are presented and historical instrumental records are used to adjust the scenarios so as to preserve the baseline climatic pattern. 
Table 1. Model data used

\begin{tabular}{|lccc|}
\hline Climate model & Lat. $\times$ Long. & $\begin{array}{c}\text { Model } \\
\text { levels }\end{array}$ & $\begin{array}{l}\Delta T\left({ }^{\circ} \mathrm{C}\right) \text { for } \\
\text { double } \mathrm{CO}_{2}\end{array}$ \\
\hline Canada (CCCM) & $3.75^{\circ} \times 3.75^{\circ}$ & 10 & 3.5 \\
GFDL R30 (GFDL3) & $2.22^{\circ} \times 3.75^{\circ}$ & 9 & 4.0 \\
GFDL transient & $4.44^{\circ} \times 7.5^{\circ}$ & 9 & 4.0 \\
(GFD01) & & & \\
\hline
\end{tabular}

The GCM models used in the study include: the Canadian Climate Centre Model (CCCM) (Houghton et al. 1990), the Geophysical Fluid Dynamics Laboratory model (GFDL3) and the GFDL transient model (Harvey 1989, Boer et al. 1992). The CCCM model was used in this study because it simulates the current precipitation rates over southern Africa with a small error margin, whereas the GFDL models have high resolution and one provides transient runs. The output from the equilibrium models consisted of $1 \times$ and $2 \times \mathrm{CO}_{2}$ runs for precipitation and surface air temperature, whereas the transient model shows anticipated precipitation and temperature changes decade by decade for 4 decades. Table 1 is a summary of the main features of the models used in the study. Precipitation and ambient temperature data from 100 stations over Zimbabwe for the period 1950 to 1980 was collated to establish the baseline climate and use this to adjust the GCM scenarios. The period 1950 to 1980 was selected because it is also the baseline used by the GCMs (Climate Handbook of Zimbabwe 1981).

Maximum and minimum ambient temperature records from several Zimbabwe stations were used for a detailed analysis of the temperature trends over the country. It is assumed that a greenhouse induced warming trend would manifest itself more clearly in

Table 2. Zimbabwe climate stations used to compile the national ambient temperature average

\begin{tabular}{|c|c|c|c|c|c|c|}
\hline \multirow[t]{2}{*}{ Name } & \multicolumn{3}{|c|}{ Mean annual (1951-80) } & \multirow{2}{*}{$\begin{array}{l}\text { Altitude } \\
\text { (m) }\end{array}$} & \multirow{2}{*}{$\begin{array}{l}\text { Latitude } \\
\text { (S) }\end{array}$} & \multirow{2}{*}{$\begin{array}{l}\text { Longitude } \\
\text { (E) }\end{array}$} \\
\hline & $\begin{array}{c}\text { Precip. } \\
\text { (mm) }\end{array}$ & $\begin{array}{l}T_{\max } \\
\left({ }^{\circ} \mathrm{C}\right)\end{array}$ & $\begin{array}{l}T_{\min } \\
\left({ }^{\circ} \mathrm{C}\right)\end{array}$ & & & \\
\hline Beitbridge & 333 & 30.1 & 16.2 & 456 & $22^{\circ} 13^{\prime}$ & $30^{\circ} 00^{\prime}$ \\
\hline Bulawayo Goetz & 597 & 25.8 & 12.6 & 1343 & $20^{\circ} 09^{\prime}$ & $28^{\circ} 37^{\prime}$ \\
\hline Chipinge & 1118 & 23.9 & 13.9 & 1131 & $20^{\circ} 12^{\prime}$ & $32^{\circ} 37^{\prime}$ \\
\hline Harare & 831 & 25.3 & 12.2 & 1471 & $17^{\circ} 50^{\prime}$ & $31^{\circ} 01^{\prime}$ \\
\hline Kwekwe & 785 & 27.3 & 12.4 & 1213 & $18^{\circ} 56^{\prime}$ & $29^{\circ} 50^{\prime}$ \\
\hline West Nicholson & 505 & 28.1 & 12.8 & 860 & $21^{\circ} 03^{\prime}$ & $29^{\circ} 22^{\prime}$ \\
\hline Mutare & 1000 & 25.0 & 13.4 & 1113 & $18^{\circ} 58^{\prime}$ & $32^{\circ} 40^{\prime}$ \\
\hline Mount Darwin & 720 & 27.2 & 12.1 & 96.5 & $16^{\circ} 47^{\prime}$ & $31^{\circ} 35^{\prime}$ \\
\hline Victoria Falls & 700 & 28.6 & 13.7 & 1061 & $18^{\circ} 06^{\prime}$ & $25^{\circ} 51^{\prime}$ \\
\hline
\end{tabular}

the night time (minimum) than in the daytime (maximum) temperatures (Kumar \& Hingane 1988). It is for this reason that minimum and maximum temperature data are used to investigate if a climate change signal already exists in Zimbabwe's climatic record. For Zimbabwe, the longest temperature record available began in 1897 at Harare and Bulawayo. For the entire country, reliable ambient temperature records began in July 1923 when thermometer shelters were replaced by the conventional Stevenson's screen. From 1900 to 1993 abundant and quality rainfall data is available and this is also the period over which most anthropogenic changes are assumed to have occurred. Because of the high inter-annual and inter-decadal variability of precipitation data, any $\mathrm{CO}_{2}$ induced trend in the precipitation pattern will be difficult to detect in a statistically significant way. The ambient temperature signal is likely to be less variable than other variables. However, on a local scale, station records may be influenced by various sources of inhomogeneity, such as site changes, changes in the type of instrument and/or its exposure, changes in observation times and/or method of producing daily and monthly averages, or local anthropogenic effects such as urban warming

Monthly mean temperature data from 1933 to 1993 at the stations listed in Table 2 were used to determine the national mean ambient temperature trends. All the stations had complete temperature records. Normalized point rainfall data from 100 stations over the period 1900 to 1993 were averaged to give a national mean which was used to investigate the long-term precipitation pattern. The historic precipitation pattern for the seasons October to December (OND), November to January (NDJ), December to February (DJF), January to March (JFM), March to May (MAM) and October to April is presented. All the climatic data were from the Zimbabwe Meteorological Department. The quality of the climatic data was consistent with international standards set by the World Meteorological Organization (Climate Handbook of Zimbabwe 1981).

Harare and Bulawayo were used to study the twentieth-century temperature patterns over urban settlements. To avoid splitting the precipitation season, the meteorological year in southern Africa starts in July and ends in June of the following calendar year. The Box-Jenkins first order autoregression model was used to investigate the existence of linear trends in both the rainfall and temperature time series (Wilks 1995). 


\section{RESULTS AND DISCUSSION}

\section{Historic temperature and rainfall variation}

The national annual mean minimum and maximum ambient temperature variations over Zimbabwe during the period 1933 to 1993 are presented in Fig. 3a, b. The annual mean minimum and maximum ambient temperature variation at Harare during 1897 to 1993 is presented in Fig. $4 a, b$. Table 3 is a summary of the surface temperature changes at Harare and the national average from 1897 to 1993 and 1933 to 1993, respectively, for the seasons DJF, MAM, JJA, SON, October through April and January through December. Fig. 3a reveals that annual mean minimum temperature trends towards cooling during 1933 to 1993. A warming trend appears in maximum temperatures during the same period (Fig. 3b). Fig. 4a, b reveals that, at Harare, both minimum and maximum temperature increased from 1897 to 1993 . Table 3 shows that the JJA season experienced the greatest increase in temperature and SON the greatest temperature decline at national level. Maximum temperatures increased by
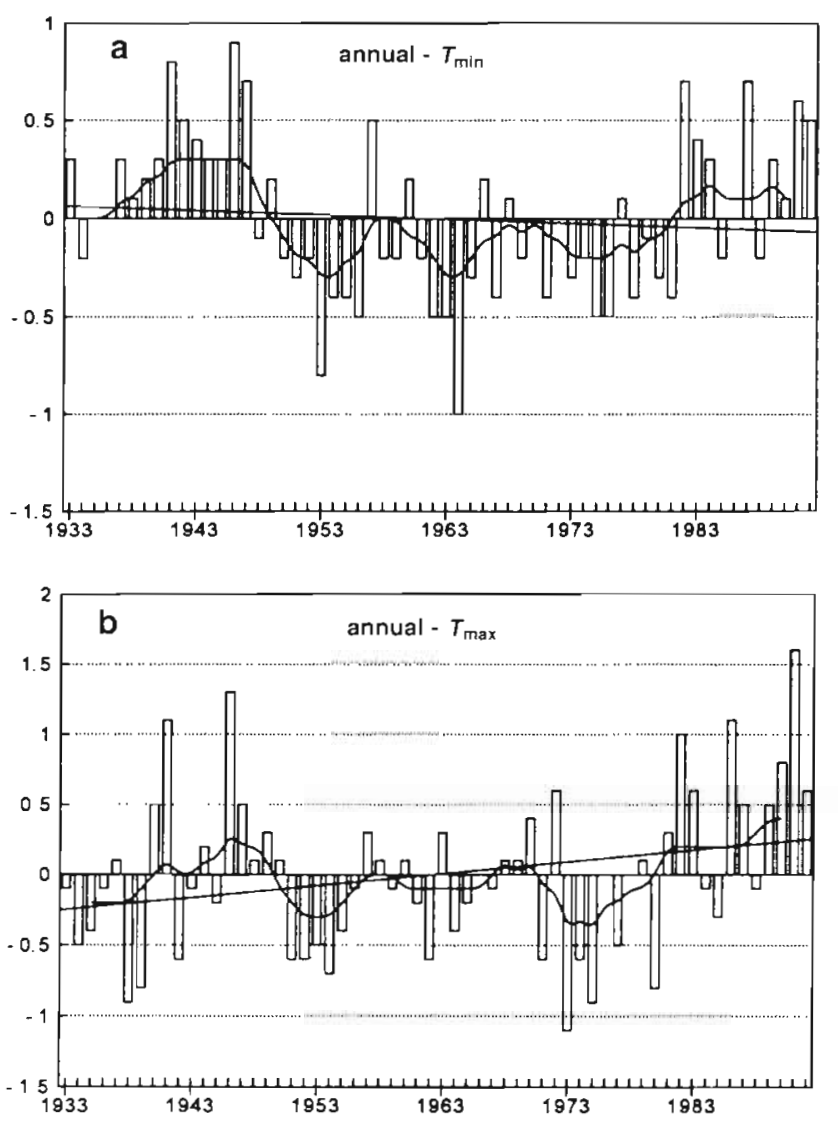

Fig. 3. Zimbabwe national mean annual ambient temperature variation from 1933 to 1993. (a) Minimum, (b) maximum temperature. The smoothed curve is the $5 \mathrm{yr}$ running mean
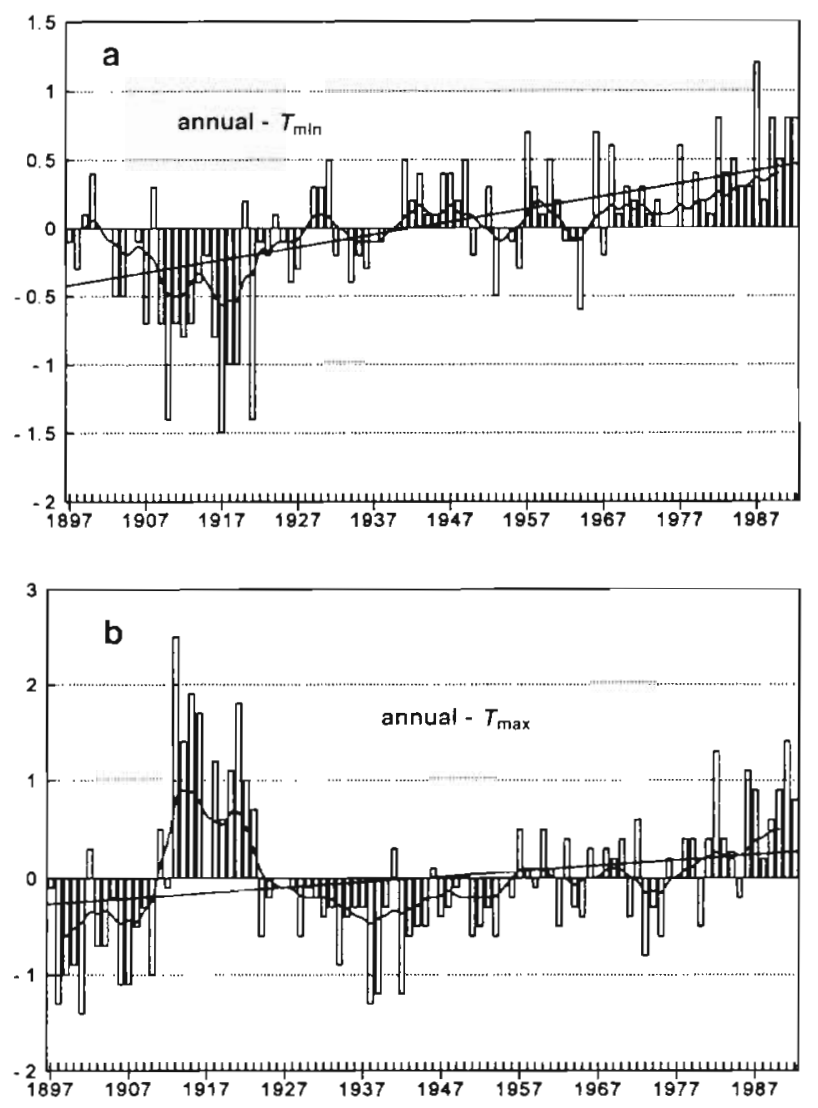

Fig. 4. Harare (Zimbabwe) mean annual ambient temperature variation between 1897 and 1993. (a) Minimum, (b) maximum temperature. The smoothed curve is the $5 \mathrm{yr}$ running mean

up to $+0.8^{\circ} \mathrm{C}$ at national level from 1933 to 1993 and by up to $+1.2^{\circ} \mathrm{C}$ at Harare from 1897 to 1993 . For the other seasons, maximum temperature increased from +0.4 to $+0.6^{\circ} \mathrm{C}$ and minimum temperature decreased by 0.2 to $0.4^{\circ} \mathrm{C}$. The ambient temperature increase over Harare has been greatest at night and could be attributed to the urban heat island effect, consistent with observations from other major cities (Kellog 1977, Angell \& Korshover 1978, Kumar \& Hingane 1988).

Table 3. Summary of ambient temperature change for Harare and Zimbabwe in the late 20th century

\begin{tabular}{|lcccc|}
\hline Season & $\begin{array}{c}\text { Harare temp. change } \\
(1897-1993)\left({ }^{\circ} \mathrm{C}\right)\end{array}$ & \multicolumn{2}{c|}{$\begin{array}{c}\text { Zimbabwe temp. change } \\
(1933-1993)\left({ }^{\circ} \mathrm{C}\right)\end{array}$} \\
& $\Delta T_{\min }$ & $\Delta T_{\max }$ & $\Delta T_{\min }$ & $\Delta T_{\max }$ \\
\hline DJF & +0.8 & +0.6 & 0 & +0.6 \\
MAM & +0.9 & +0.8 & 0 & +0.6 \\
JJA & +1.2 & +0.7 & -0.2 & +0.8 \\
SON & +1.0 & +0.1 & -0.4 & 0 \\
Oct-Apr & +0.8 & +0.4 & -0.2 & +0.4 \\
Jan-Dec & +0.9 & +0.6 & -0.2 & +0.6 \\
\hline
\end{tabular}



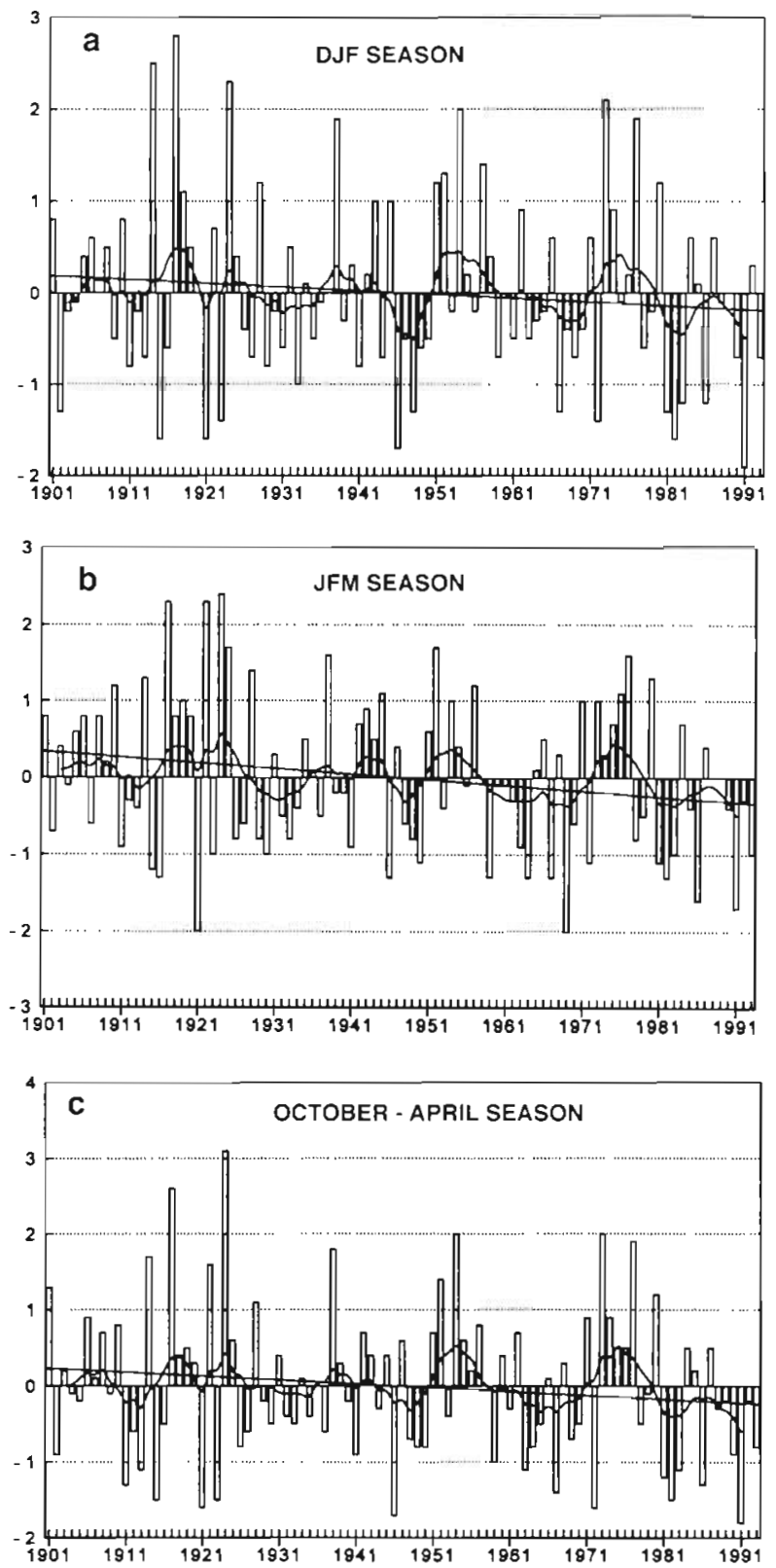

Fig. 5. Variation in the Zimbabwe national mean normalized precipitation departure from normal between 1900 and 1994 for the seasons (a) December to February, (b) January to March, and (c) October to April. The smoothed curve shows the 5 yr running mean

Both the national mean minimum and maximum ambient temperature time series show 2 phases of temperature increase. The first warming phase was from 1935 to 1949 and the second phase was from 1980 to present (Fig. 3). A long relative temperature decline separates the 2 warm phases. The net temperature increase during the 2 warm phases was about +0.3 to $+0.5^{\circ} \mathrm{C}$, whereas the cool phase had a net temperature decline of about -0.2 to $-0.3^{\circ} \mathrm{C}$.
Table 4. Precipitation change over Zimbabwe between 1900 and 1994

\begin{tabular}{|lcccccc|}
\hline Season & OND & NDJ & DJF & JFM & FMA Oct-Apr \\
\hline$\%$ change & 0 & $-10 \%$ & $-10 \%$ & $-16 \%$ & $-10 \%$ & $-10 \%$ \\
\hline
\end{tabular}

The national normalized rainfall anomaly time series is shown in Fig, $5 a$ to $\mathrm{C}$ for the DJF, JFM and October to April seasons for the period 1900/01 to 1993/94. Table 4 summarizes the observed national average precipitation changes from 1900/01 to 1993/94. Fig. 5 reveals that Zimbabwe was characterized by low precipitation during the late 1920 s to 1949, late 1950 to about 1972 and from 1980 to present. Both warm phases were during two of these relatively dry periods. The scatterplot of rainfall and maximum temperature anomalies in Fig. 6 shows the existence of a negative association between high daytime ambient temperatures and rainfall anomalies over Zimbabwe $(r=-0.822, n=60)$. Therefore, the warm phases in the ambient temperature time series could be partially explained by persistent drought episodes.

Fig. 5 shows a declining trend in precipitation over Zimbabwe during the seasons DJF, JFM and October to April, respectively. Table 4 reveals that national average precipitation has declined by about $10 \%$ during the October to April season from 1900 to 1994 . This magnitude of change represents about 0.4 standard deviations. During the DJF and JFM seasons, precipitation has decreased by 10 and $16 \%$, respectively (Table 4). Hulme (1992) reports a similar magnitude of change in the austral summer (DJF) daily precipitation rates over parts of Zimbabwe between 1931-1960 and 1961-1990.

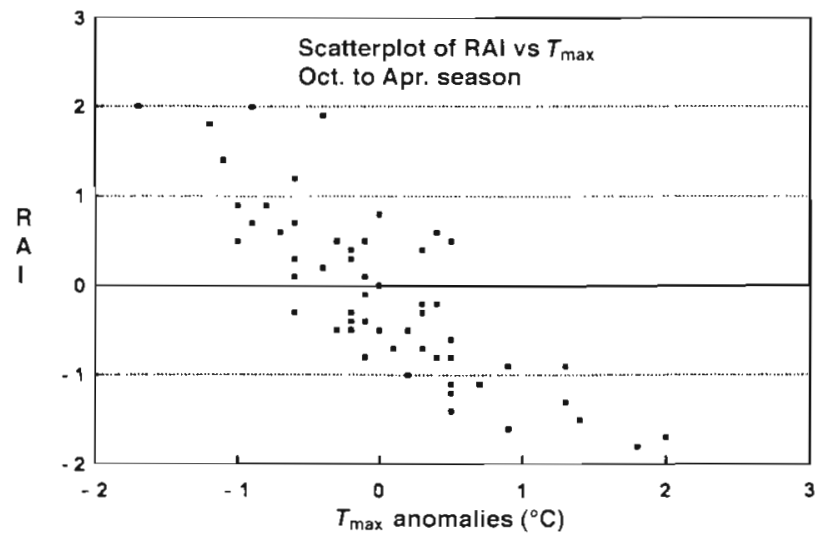

Fig. 6. National average precipitation anomaly index (RAI) versus maximum ambient temperature departure from normal 
(a)

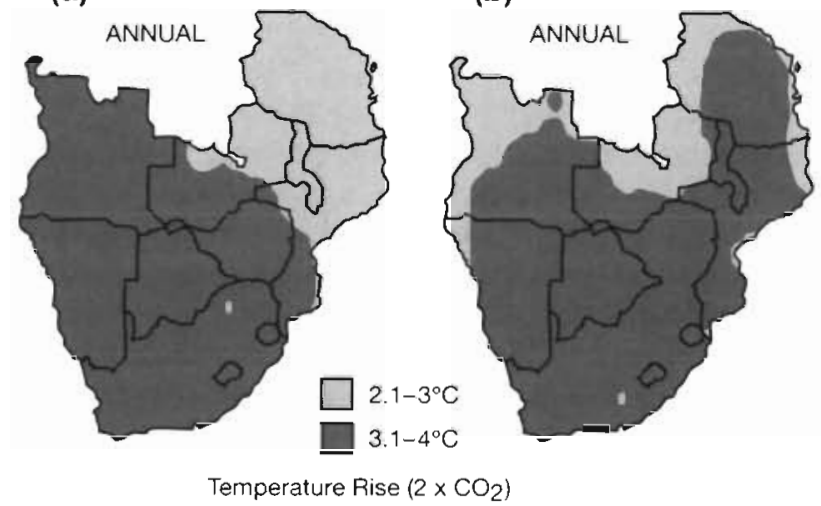

Fig. 7 Mean ambient temperature scenarios simulated by (a) CCCM and (b) GFDL3 model, under double $\mathrm{CO}_{2}$ atmospheric conditions

\section{GCM based climate scenarios for southern Africa}

The annual surface ambient temperature scenarios from 2 equilibrium GCMs used in this study, the CCCM and GFDL3 respectively, are presented in Figs. 7 \& 8 . Both models simulate changes in mean surface air temperature of +2 to $+4^{\circ} \mathrm{C}$ across southern Africa under double $\mathrm{CO}_{2}$ conditions. Results from the 2 models are in close agreement on the magnitude of temperature rise to anticipate as a result of double atmospheric $\mathrm{CO}_{2}$. However, there is slight divergence on the spatial distribution of the changes as shown in Figs. $7 \& 8$. The GFDL transient model projects a temperature rise of 2 to $4^{\circ} \mathrm{C}$ by the end of the next 10 decades from the 1980-90 decade. The magnitudes of increases projected by both models are consistent with global projections in the Southern Hemisphere (Pittock \& Salinger 1991).

Table 5 is a summary of the precipitation scenarios from the $3 \mathrm{GCMs}$ used in this study. Fig. 8 shows the CCCM and GFDL3 simulations of areas in southern Africa that are likely to experience a decline or increase in precipitation at $2 \times \mathrm{CO}_{2}$ during the October to April season. Table 5 reveals that the GFDL3 model simulates a 15 to $20 \%$ increase in precipitation across southern Africa during October to April. The CCCM simulates a 16 to $21 \%$ increase during the same seasons but for different regions (Fig. 8). In general, the GCMs used in this study suggest that some areas in southern Africa will experience an increase in precipitation of about 10 to $15 \%$ on average whereas others will experience decreases of a similar magnitude. (a)

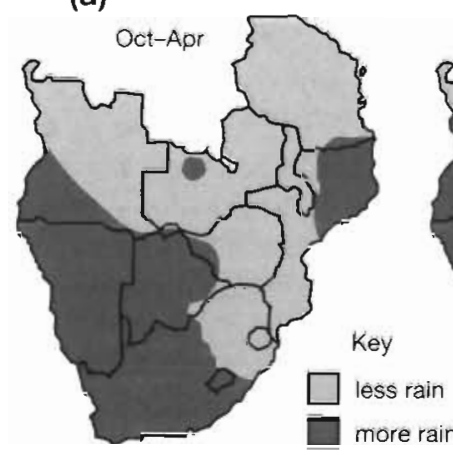

(b)

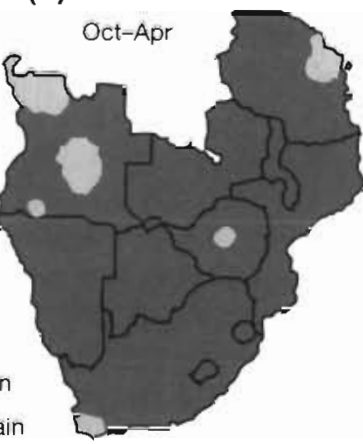

Fig. 8. Scenarios of precipitation change during the October to April season as simulated by (a) CCCM and (b) GFDL3 model, under double $\mathrm{CO}_{2}$ atmospheric conditions

Data on past climate in southern Africa is not sufficiently complete to allow any unambiguous testing. Having presented the climate scenarios from the GCMs, it is important to test and validate the reliability of the projections. A model is considered reliable if it can simulate the current climate accurately, there is similarity of results for changed conditions between different models, or there is emergence of a climate change signal from the real atmosphere that conforms to model predictions (Houghton et al. 1992).

A comparison of the observed baseline climate and the model simulated climate shows that the CCCM model underestimates the baseline temperature in the low altitude areas of southern Africa by up to $4{ }^{\circ} \mathrm{C}$, while overestimating temperature for highland areas by a similar margin. However, the same model appears to simulate precipitation with an error margin of under

Table 5. Summary of GCM precipitation projections for $2 \times \mathrm{CO}_{2}$ and $1 \%$ $\mathrm{CO}_{2}$ rise per annum scenarios

\begin{tabular}{|c|c|c|c|c|c|c|}
\hline & \multicolumn{6}{|c|}{$\mathrm{CCCM}$ (equilibrium model) $2 \times \mathrm{CO}_{2}$} \\
\hline & SON & DJF & $\mathrm{O}-\mathrm{A}$ & SON & DJF & $\mathrm{O}-\mathrm{A}$ \\
\hline \multirow[t]{3}{*}{$\%$ change } & 17 & 21 & 16 & 10 & 12 & 10 \\
\hline & \multicolumn{6}{|c|}{ GFDL3 (equilibrium model) $2 \times \mathrm{CO}_{2}$} \\
\hline & SON & DJF & $\mathrm{O}-\mathrm{A}$ & $\mathrm{SON}$ & DJF & $\mathrm{O}-\mathrm{A}$ \\
\hline \multirow[t]{4}{*}{$\%$ change } & 15 & 19 & 15 & 11 & 9 & 7 \\
\hline & \multicolumn{6}{|c|}{ GFDL transient ( $1 \%$ rise in $\mathrm{CO}_{2}$ per annum) } \\
\hline & \multicolumn{3}{|c|}{ Average $\%$ increase } & \multicolumn{3}{|c|}{ Average $\%$ decrease } \\
\hline & OND & JFM & $\mathrm{O}-\mathrm{A}$ & OND & JFM & $\mathrm{O}-\mathrm{A}$ \\
\hline Decade 1 to 3 & 20 & 24 & 14 & 15 & 15 & 10 \\
\hline Decade 1 to 7 & 22 & 31 & 17 & 13 & 11 & 8 \\
\hline Decade 1 to 10 & 27 & 28 & 17 & 15 & 18 & 11 \\
\hline
\end{tabular}


$10 \%$. In contrast, the GFDL model overestimates precipitation rates in the region by 100 to $300 \%$. As an example, the GFDL3 model simulates baseline precipitation rates of 4.1 to $6.0 \mathrm{~mm} \mathrm{~d}^{-1}$ during the October to April season over Zimbabwe, instead of the observed rates of 1.9 to $5.8 \mathrm{~mm} \mathrm{~d}^{-1}$. The same model underestimates the baseline ambient temperature in low altitude areas by about $3^{\circ} \mathrm{C}$, while overestimating that for the cooler highland areas by a similar margin.

\section{Instrumental record adjusted scenarios}

To validate the baseline climate pattern, instrumental records of ambient temperature and precipitation were used to redraw the GCM climate scenarios for Zimbabwe. The GCM models simulate a mean increase and decline in precipitation of about $10 \%$ at $2 \times \mathrm{CO}_{2}$ and a temperature change ranging from +1 to $+4^{\circ} \mathrm{C}$. Using those trends as a basis, precipitation and temperature scenarios for Zimbabwe were redrawn from the 1950-80 baseline climate.

Instrument record adjusted scenarios for a $10 \%$ decrease or increase in precipitation are shown in Fig. $9 a, b$, respectively, for the October to April rainy season. Assuming that the rainfall over Zimbabwe continues to vary as it has in the past and that the GCM simulations are correct, then the $2 \times \mathrm{CO}_{2}$ precipitation scenario over Zimbabwe will be as shown in Fig. 9a. However, if precipitation increases, as suggested by some GCMs, then the $2 \times \mathrm{CO}_{2}$ precipitation scenario for Zimbabwe for assuming a $10 \%$ increase will be as shown in Fig. 9b. From Fig. 9a, for the $700 \mathrm{~mm}$ contour, a $10 \%$ drop in precipitation represents a $78 \mathrm{~mm}\left(0.4 \mathrm{~mm} \mathrm{~d}^{-1}\right)$ decline in precipitation, whereas for the $500 \mathrm{~mm}$ contour that represents a $56 \mathrm{~mm}$ ( $\left.0.3 \mathrm{~mm} \mathrm{~d}^{-1}\right)$ decline. Such climate change may have adverse impacts on the current agricultural systems and the country's hydrological balance (Rosenzweig \& Parry 1994).

Fig. 10a, b shows the annual mean minimum (TN) and maximum (TX) baseline temperature for Zimbabwe from 1951 to 1980 . Ambient temperatures in Zimbabwe increase from the central highland areas toward the Zambezi Valley (northwest) and the southeastern lowlands. If the mean minimum and maximum temperatures were to increase by $1^{\circ} \mathrm{C}$, the implications are that the current temperature regime typical of the Zambezi Valley and the southeastern lowlands of Zimbabwe will spread inwards towards the central highlands. Using the October to April season as an example, a $1^{\circ} \mathrm{C}$ rise in daytime temperatures would result in the current $28^{\circ} \mathrm{C}$ contour becoming $29^{\circ} \mathrm{C}$, whereas a $4^{\circ} \mathrm{C}$ rise would result in the same contour being $32^{\circ} \mathrm{C}$. Such temperature increases will result in 

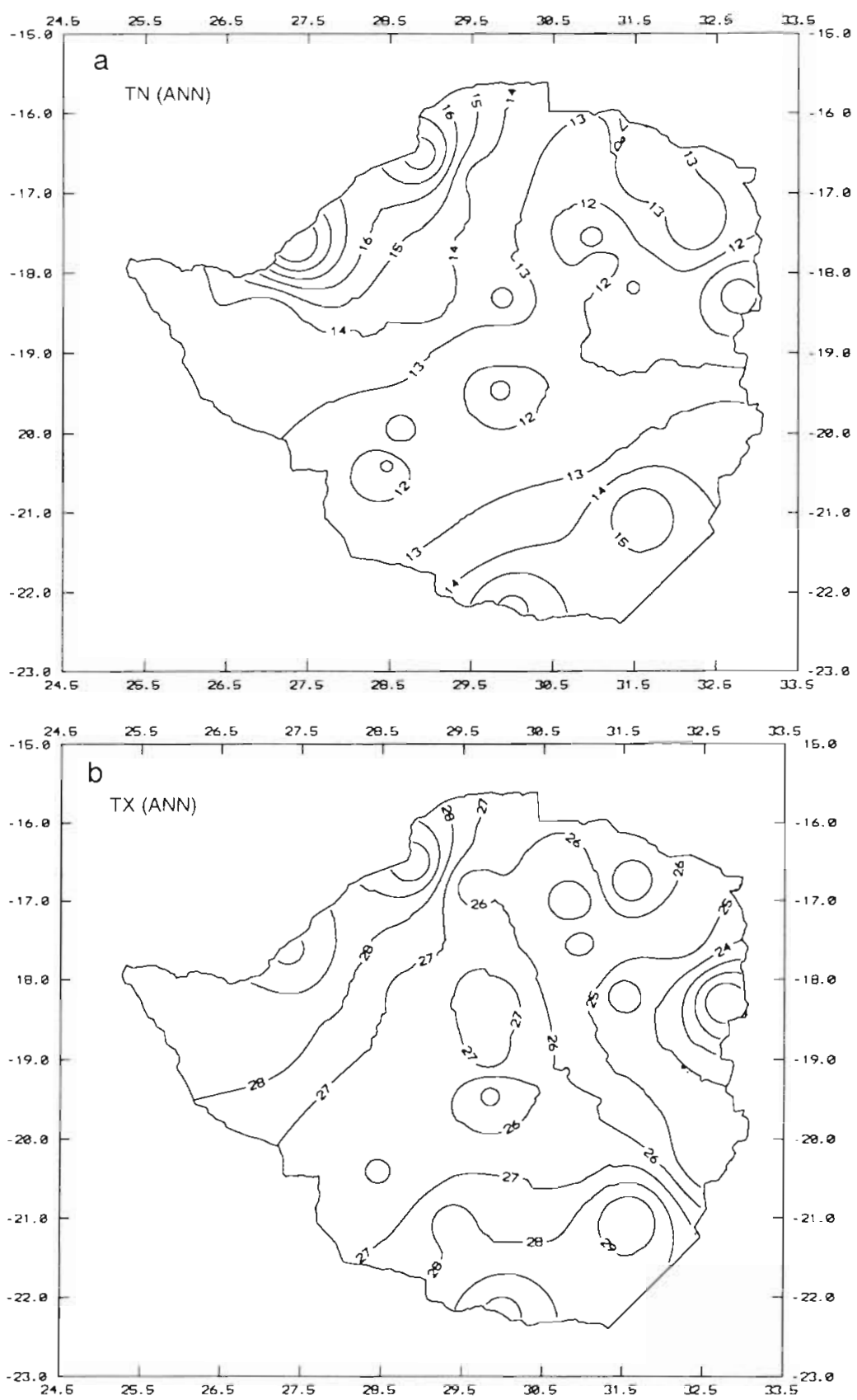

Fig. 10. Zimbabwe baseline ambient temperature pattern for (a) minimum and (b) maximum temperature

\section{CONCLUSIONS}

From this study it can be concluded that daytime temperatures over Zimbabwe have risen by up to $0.8^{\circ} \mathrm{C}$ from 1933 to 1993 , which translates to a $0.1^{\circ} \mathrm{C}$ rise per decade. Precipitation has declined by up to $10 \%$ on average over the period 1900 to 1993 , which is about $1 \%$ per decade. It can also be concluded that warming has been greatest over urban settlements, where both nighttime and day-time temperatures show an increase, consistent with the heat island effect. On a national average, minimum ambient temperatures show a cooling trend, whereas maximum temperature shows a warming trend. It is difficult at this stage to attribute the observed climatic trends to any single factor. Hulme (1992) proposed 3 possible broad categories to explain precipitation changes observed over Africa between 1931-1960 and 1961-1990. The 3 categories are mainly: land cover changes, changes in the global ocean circulation and associated sea-surface temperature (SST) patterns and the changing composition of the atmosphere.

GCM scenarios for a $2 \times \mathrm{CO}_{2}$ atmosphere suggest temperature increases ranging from 1 to $4^{\circ} \mathrm{C}$ across southern Africa and precipitation changes ranging from \pm 10 to $15 \%$ on average during the October to April season. Current models are insufficient to predict the direction or magnitude of precipitation change (Mitchell 1990). There is general agreement between the models that, as a result of warmer oceans and a warmer landmass, the precipitation in much of the Southern Hemisphere is likely to increase by about $10 \%$ on average, as evaporation from the oceans increases and the monsoon winds strengthen. Mabbutt (1989) even

unprecedented evaporation rates and if unmatched with precipitation increases, much of the western and southern half of Zimbabwe could become arid. Given the observation that, over the past $93 \mathrm{yr}$, daytime temperatures over $\mathrm{Zimbabwe}$ rose by about $0.8^{\circ} \mathrm{C}$, it is reasonable to assume that a $1{ }^{\circ} \mathrm{C}$ rise within the next $100 \mathrm{yr}$ will be surpassed depending on the future greenhouse gas emissions and resulting shifts in atmospheric chemistry and physics. suggests the possibility of the precipitation season these model projections, the climate of southern Africa has been highly variable for millennia and will most likely continue to be so in future. The countries of southern Africa are lands of drought rather than lands of abundant precipitation. All future climate security planning should be based on this assumption (Rosenzweig \& Parry 1994). lengthening by 2 to $4 \mathrm{wk}$ in some regions. Despite all 
The El Niño-Southern Oscillation (ENSO) phenomenon is a major cause of the high interannual variability of climate over much of southern Africa (Tyson 1986. Ropelewski \& Halpert 1987). Reliable climate predictions for the Southern Hemisphere cannot be developed without considering the influence of ENSO (Walker \& Dickson 1991). If global climate change alters the behavior of ENSO, this may offset or enhance regional climate changes associated with ENSO effects. If ENSO entered more frequently into strong temperature decline phases, this could mean higher precipitation over southern Africa in general. It is not possible yet to predict how ENSO will react to global climate change. A coupled ocean-atmosphere model capable of realistically simulating present ENSO behavior is needed. Such GCMs are being developed in several countries (Walker \& Dickson 1991). However, at present the best guess for the state of the ENSO phenomenon under a warmer earth is that it will continue to occur quasi-periodically, as it does today (Pittock \& Salinger 1991). The implications are that the large year-to-year climatic variability of areas affected by ENSO will continue and probably be superimposed on any change in mean conditions.

Acknowledgements. This study was sponsored by the U.S. Country Studies Program.

\section{LITERATURE CITED}

Angell JK, Korshover J (1978) Global temperature variation, Surface-100 mb: an update into 1977 Mon Weather Rev 106:75.5-70

Boer GJ, MCFarlane NA, Lazaro M (1992) Greenhouse gasinduced climate change simulated with the $\mathrm{CCC}$ secondgeneration general circulation model. Bull Am Meteorol Soc 5:1045-1077

Bolin B, Doos BR, Jager J, Warrick RA (eds) (1986) The greenhouse effect, climatic change and ecosystems. John Wiley \& Sons, Chichester

Climate Handbook of Zimbabwe (1981) Department of Meteorological Services, Harare
Harvey LDD (1989) Transient climatic response to an increase of greenhouse gases. Clim Change 15:15-30

Houghton JT, Callendar BA, Varney SK (eds) (1992) Climate change 1992: the IPCC supplementary report on the IPCC scientific assessment. Cambridge Univ Press, Cambridge

Houghton JT, Jenkins GJ, Ephraums JJ (eds) (1990) Climate change: the IPCC scientific assessments. Cambridge University Press, New York

Hulme M (1992) Rainfall changes in Africa: 1931-1960 to 1961-1990. Int J Clim 12:685-699

Idso SB (1993) Carbon dioxide and global change: earth in transition. IBR Press, New York

Kellog WW (1977) Effects of human activities on global change - Part 1 WMO Bull 26:229-239

Kumar K. Hingane LS (1988) Long-term variations of surface air temperature over major industrial cities of India. Clim Change 13:287-307

Mabbutt JA (1989) Impacts of carbon dioxide warming on climate and man in the semi-arid tropics. Clim Change 15: 191-222

Mitchell JM Jr (1990) Climatic variability: past, present and future. Clim Change 16:231-246

Oppenheimer M (1989) Climate change and environmental pollution: physical and biological interactions. Clim Change 15:255-270

Pearman Gl (1991) Changes in atmospheric chemistry and the greenhouse effect: a Southern Hemisphere perspective. Clim Change 18:131-146

Pittock AB, Salinger MJ (1991) Southern Hemisphere climate scenarios. Clim Change 18:205-222

Ropelewski CF, Halpert MS (1987) Global and regional scale precipitation patterns associated with the El Nino/Southern Oscillation. Mon Weather Rev 115:1606-1626

Rosenzweig C, Parry ML (1994) Potential impact of climate change on world food supply. Nature 367:133-138

Todorov AV, Steyaert LT(1983) Agroclimatix conditions and assessment methods for drought/food shortages in subequatorial Africa. Tech Report, Int Dev Coop Agency, Washington, DC

Tucker GB (1991) Confidence in modelling future climate: a Southern Hemisphere perspective. Clim Change 18: $195-204$

Tyson PD (1986) Climate change and variability in southern Africa. Oxford Univ Press, Oxford, p 220

Walker BH, Dickson RG (1991) Global change: issues for the Southern Hemisphere. Clim Change 18:115-120

Wilks DS (1995) Statistical methods in atmospheric sciences, an introduction. Academic Press, New York 